\title{
Lysyl oxidases: linking structures and immunity in the tumor microenvironment
}

\author{
Paolo Tenti ${ }^{1,2}$ (D) Luca Vannucci ${ }^{1}$ (i)
}

Received: 22 June 2019 / Accepted: 24 September 2019 / Published online: 25 October 2019

(c) The Author(s) 2019

\begin{abstract}
The lysyl oxidases (LOXs) are a family of enzymes deputed to cross-link collagen and elastin, shaping the structure and strength of the extracellular matrix (ECM). However, many novel "non-canonical" functions, alternative substrates, and regulatory mechanisms have been described and are being continuously elucidated. The activity of LOXs, therefore, appears to be integrated into a complex network of signals regulating many cell functions, including survival/proliferation/differentiation. Among these signaling pathways, TGF- $\beta$ and PI3K/Akt/mTOR, in particular, cross-talk extensively with each other and with LOXs also initiating complex feedback loops which modulate the activity of LOXs and direct the remodeling of the ECM. A growing body of evidence indicates that LOXs are not only important in the homeostasis of the normal structure of the ECM, but are also implicated in the establishment and maturation of the tumor microenvironment. LOXs' association with advanced and metastatic cancer is well established; however, there is enough evidence to support a significant role of LOXs in the transformation of normal epithelial cells, in the accelerated tumor development and the induction of invasion of the premalignant epithelium. A better understanding of LOXs and their interactions with the different elements of the tumor immune microenvironment will prove invaluable in the design of novel anti-tumor strategies.
\end{abstract}

Keywords Lysyl oxidases · Tumor microenvironment · Immunity · Extracellular matrix structure · TGF- $\beta$ CITIM 2019

\begin{tabular}{|c|c|c|c|}
\hline \multicolumn{2}{|c|}{ Abbreviations } & EMT-TFs & Epithelial-mesenchymal transition tran- \\
\hline AP-1 & Activator protein-1 & & scription factors \\
\hline BAPN & Beta-aminopropionitrile & $\mathrm{ECM}$ & Extracellular matrix \\
\hline BMP-1 & Bone morphogenetic protein-1 & ERK & Extracellular signal-regulated protein \\
\hline CAF & Cancer-associated fibroblasts & & kinase \\
\hline JNK & c-Jun N-terminal kinase & FAK & Focal adhesion kinase \\
\hline CDKs & Cyclin-dependent kinases & FoxM1b & Forkhead box M1b \\
\hline EGF & Epidermal growth factor & GATA-3 & GATA-binding protein 3 \\
\hline \multirow[t]{2}{*}{ EMT } & Epithelial-mesenchymal transition & GSK3B & Glycogen synthase kinase- 3 beta \\
\hline & & HTRA1 & $\begin{array}{l}\text { High-temperature requirement A serine } \\
\text { peptidase } 1\end{array}$ \\
\hline \multirow{4}{*}{\multicolumn{2}{|c|}{$\begin{array}{l}\text { This paper is a Focussed Research Review based on a presentation } \\
\text { given at the Sixth International Conference on Cancer } \\
\text { Immunotherapy and Immunomonitoring (CITIM 2019), held in } \\
\text { Tbilisi, Georgia, 29th April-2nd May 2019. It is part of a series of } \\
\text { CITIM } 2019 \text { papers in Cancer Immunology, Immunotherapy. }\end{array}$}} & $\begin{array}{l}\text { Hic-5 } \\
\text { HIF-1 }\end{array}$ & $\begin{array}{l}\text { Hydrogen peroxide-1nducibl } \\
\text { Hypoxia-inducible factor- } 1\end{array}$ \\
\hline & & HRE & Hypoxia-responsive element \\
\hline & & LLC & Large latent complex \\
\hline & & LAP & Latency-associated protein \\
\hline \multirow{3}{*}{\multicolumn{2}{|c|}{$\begin{array}{l}\text { Luca Vannucci } \\
\text { vannucci@biomed.cas.cz }\end{array}$}} & LTBP & Latent TGF- $\beta$-binding protein \\
\hline & & LOX & Lysyl oxidase \\
\hline & & LOX-PP & Lysyl oxidase pro-peptide \\
\hline \multirow{2}{*}{ ( } & \multirow{3}{*}{$\begin{array}{l}\text { Laboratory of Immunotherapy, Institute of Microbiology } \\
\text { of the Czech Academy of Sciences, Videnska 1083, } \\
14220 \text { Prague 4, Czech Republic }\end{array}$} & LOXL & Lysyl oxidase-like \\
\hline & & LOXs & Lysyl oxidases \\
\hline & & LTQ & Lysyl tyrosyl quinone \\
\hline $\begin{array}{r}\text { Facul } \\
1280\end{array}$ & $\begin{array}{l}\text { ence, Charles University, Albertov 6, } \\
\text {, Czech Republic }\end{array}$ & mTOR & Mammalian target of rapamycin \\
\hline
\end{tabular}




$\begin{array}{ll}\text { MATN2 } & \text { Matrilin2 } \\ \text { MMP } & \text { Matrix metalloproteinase } \\ \text { p-isoforms } & \text { Phospho-isoforms } \\ \text { PAI-1 } & \text { Plasminogen activator inhibitor-1 } \\ \text { PDGF } & \text { Platelet-derived growth factor } \\ \text { Akt } & \text { Protein kinase B } \\ \text { RhoA/ROCK } & \begin{array}{l}\text { Ras homolog family member A/Rho-asso- } \\ \text { ciated protein kinase }\end{array} \\ \text { SRCR } & \text { Scavenger receptor cysteine-rich domains } \\ \text { pSmad2C } & \text { Smad2 phosphorylated at the C terminus } \\ \text { pSmad2L/C } & \text { Smad2 phosphorylated in the middle } \\ & \text { linker region and at the C terminus } \\ \text { pSmad2L } & \text { Smad2 phosphorylated in the middle } \\ & \text { linker region } \\ \text { pSmad3C } & \text { Smad3 phosphorylated at the C terminus } \\ \text { pSmad3L } & \text { Smad3 phosphorylated in the middle } \\ & \text { linker region } \\ \text { pSmad3L/C } & \text { Smad3 phosphorylated in the middle } \\ & \text { linker region and at the C terminus } \\ \text { SLC } & \text { Small latent complex } \\ \text { Smad } & \text { Small mother against decapentaplegic } \\ \text { SDF-1 } & \text { Stromal cell-derived factor-1 } \\ \text { TGF } \beta R I & \text { TGF- } \beta \text { receptor type I } \\ \text { TIMP-1 } & \text { Tissue inhibitor of metalloproteinase-1 } \\ \text { TIME } & \text { Tumor immuno-microenvironment } \\ \text { TME } & \text { Tumor microenvironment } \\ \text { INT } \beta & \beta \text {-Integrin } \\ \alpha \text {-SMA } & \alpha \text {-Smooth muscle actin } \\ & \end{array}$

\section{Introduction}

The classically described function of the lysyl oxidases (LOXs) as collagen and elastin cross-linkers could suggest a role restricted to the regulation of the extracellular matrix (ECM). In reality, the activity of LOXs integrates a complex network within the tissue microenvironment (either normal or pathologic) linking bi-directionally the ECM, the immunological components, and the signaling pathways regulating cell survival/proliferation/differentiation. A change in each of these elements propagates to another and LOXs are often involved as key mediators of these changes. The complex cross-talk between these elements of the tissue microenvironment is only partially understood, because the LOXs are involved in a broad spectrum of "non-canonical" functions, such as oxidation of alternative substrates or alternative signaling pathways which only recently have started being elucidated.

We have here reviewed some of these alternatives or recently described pathways and functions, as well as the classical older and most studied ones. Particular importance has been given to the mechanisms commonly dysregulated in cancer and especially relevant to the ECM remodeling and tumor microenvironment (TME) establishment. A special effort has been profuse in trying to illustrate their intricacy and interdependence and proposing some hypothesis on their cancer-related functional aspects.

\section{LOXs: structure, activation, and physiology}

Lysyl oxidase (LOX) family members include five copperdependent amino-oxidases: LOX, and lysyl oxidase-like 1-4 (LOXL-1, LOXL-2, LOXL-3, and LOXL-4). All of them present a highly conserved carboxy-terminal region containing a cytokine-rich domain and the catalytic domain, which includes a lysyl tyrosyl quinone (LTQ) cofactor and a copper-binding site characterized by a histidine-rich motif [1-3]. The catalytic domain is responsible for the oxidative deamination of the $\varepsilon$-amino groups of lysine and hydroxylysine residues to form highly reactive allysine residues; these tend to condense spontaneously among them or with non-oxidized lysine to form intramolecular and intermolecular covalent bonds (cross-linking). Collagen and elastin are the canonical substrates, and their cross-linking provides mechanical resistance and structural integrity of the ECM [4].

The N-terminal region, except for the signal peptide, is instead poorly conserved. The LOX translated peptide, which has a predicted M.W. of $48 \mathrm{kDa}$ (pre-LOX), is subjected to signal peptide removal and $\mathrm{N}$-glycosylation before being secreted extracellularly as the $50 \mathrm{kDa}$ immature form (pro-LOX). After that, the $\mathrm{N}$-terminal $18 \mathrm{kDa}$ lysyl oxidase pro-peptide (LOX-PP) needs to be cleaved by the bone morphogenetic protein-1/pro-collagen $\mathrm{C}$ metalloproteinase (BMP-1) to release the active enzyme [5, 6]. Unlike LOX, the immature LOXL-1 presents a proline-rich domain contained in the N-terminal region and has a predicted M.W. of $63 \mathrm{kDa}$. BMP-1 also activates it; however, the maturation site is not clear, with reports of Western Blotting bands of $66,55,41$, and $33 \mathrm{kDa}$ following the BMP-1 cleavage [1]. LOXL-2, LOXL-3, and LOXL-4 present even more divergent $\mathrm{N}$-terminal regions, which contain four consecutive scavenger receptor cysteine-rich domains (SRCR) [7]. These LOX family members have a predicted M.W. of 87 , 80.3 , and $82 \mathrm{kDa}$, respectively, and in contrast with LOX and LOXL-1, it is uncertain if they require a proteolytic cleavage for their activation [8, 9]. LOXL-2 observed size is around $100 \mathrm{kDa}$ both intracellularly and extracellularly, presumably exceeding the predicted size of $87 \mathrm{kDa}$ because of $\mathrm{N}$-glycosylation or other types of post-translational modifications [10]. Several studies have also characterized a $65 \mathrm{kDa}$ extracellular form as a processed LOXL-2 [10, 11]; after the extracellular secretion, in fact, LOXL-2 can be cleaved by a serine protease in the $\mathrm{N}$-terminal region with 
the consequent removal of the first two SRCR domains. This modification has been shown not to increase LOXL-2 amine oxidase activity with small soluble substrates; however, it is required to stabilize the insoluble scaffold of the collagen IV of the basement membrane. The tridimensional collagen IV scaffold of basement membrane results from both hexameric interactions of two protomers at the $\mathrm{C}$ terminus and dodecameric interactions of four protomers at the $\mathrm{N}$ terminus. Two protomers interact at the $\mathrm{C}$ terminus through the noncollagenous globular C-terminal domain ( $\mathrm{NC} 1)$, while four protomers interact at the $\mathrm{N}$ terminus through the $7 \mathrm{~S}$ domains (7S Dodecamer). Only the $65 \mathrm{kDa}$ form of LOXL-2 can cross-link the 7S Dodecamer and stabilize the collagen IV tridimensional scaffold of the basement membrane [10]. Potential effects of LOXL-2 processing on collagen I and III or other substrates, however, have not been investigated yet.

Based on a phylogenetic analysis of the conserved domains and similarity of the N-terminal region, LOXs can be separated in a first group, including LOX and LOXL1 , and a second group including LOXL-2, LOXL-3, and LOXL-4 [12]. The former group is thought to be phylogenetically newer and preferentially associated with the cross-linking of phylogenetically newer substrates, such as fibrillar collagen (I and III) and elastin; therefore, LOX and LOXL-1 are considered matrix-oriented enzymes, and indeed, they interact with other ECM proteins such as BMP-1, fibronectin, fibulin 4 and 5, and tropoelastin [12]. Being responsible for intrafibrillar and interfibrillar crosslinking, they are fundamental for genesis and maintenance of the fibrillar structure, size, shape, spacing, and mechanical strength [13]. Their function is equally important in the elastogenesis. Experiments in LOX and LOXL-1 knock-out mice showed a predominant role of LOX in the fibrillogenesis and of LOXL-1 in the elastogenesis [14, 15]. LOXL-2, LOXL-3, and LOXL-4, instead, with their SRCR domains phylogenetically old and conserved, might act preferentially as crosslinkers of the basement membrane (collagen IV) and be more firmly in control of the ECM stiffness [16]. Furthermore, the SRCR domains are likely to mediate protein-protein interactions to extend the spectrum of substrates or signaling capabilities of LOXL-2, LOXL-3, and LOXL-4; indeed, SRCR domains are frequently encountered in the structure of the pattern recognition receptors $[1,17]$.

\section{LOXs and mechanisms of regulation/ dysregulation}

It is increasingly recognized that the ECM and its reorganization are of paramount importance in the evolution of both tumor and immune microenvironment, as well for their interaction $[18,19]$. LOXs are critical players in the ECM homeostasis, and in fact, their dysregulation is involved in several pathologies, including fibrosis and cancer. Advancing our knowledge on LOXs and their regulation mechanisms is, therefore, paramount to understand the events leading to the TME evolution, both in the early stages (where increasing pro-survival and proliferation stimuli as well as blunted immune surveillance start to manifest), and in more advanced stages, characterized by the appearance of invasive and metastatic phenotypes.

TGF- $\beta$ can be considered the master regulator of the ECM, modulating the expression of both structural and enzymatic proteins, and this way orchestrating deposition, modification, and degradation of collagen and other ECM components. It is a crucial factor in the maturation of the tumor immuno-microenvironment (TIME): besides its activity on the ECM, TGF- $\beta$ is a cytokine with a well-recognized role in promoting the differentiation of the T-helper progenitors toward regulatory $\mathrm{T}$ cells and is, therefore, thought to be instrumental in blunting the immune surveillance and permitting the tumor development. Furthermore, TGF- $\beta$ dual role either as a tumor suppressor or as a promoter can be exploited by the tumor by progressively shifting this cytokine activity from prevalently cytostatic in normal epithelial cells to prevalently immune suppressive and pro-carcinogenetic in the TME [20, 21].

In the canonical TGF- $\beta$ pathway, a family of proteins called Smad (small mother against decapentaplegic) transduces the signals from the TGF- $\beta$ receptor to the nucleus. TGF- $\beta$ receptor type I (TGF $\beta$ RI) phosphorylates Smad 2 and Smad3, enabling the binding with the co-factor Smad4 and the formation of active complexes which enter the nucleus. Importantly, Smad 4 can bind and activate the Lox promoter [22].

A study in cardiac fibroblasts showed a concomitant upregulation of both LOX, collagen type I and III, and BMP-1 following TGF- $\beta$ stimulation. LOX upregulation was time and dose-dependent and was abrogated by the inhibition of any of either Smad3, PI3K/Akt (phosphatidylinositol 3-kinase/protein kinase B) or MAPK signaling. PI3K/ Akt and MAPK are known to increase TGF- $\beta$ expression by inducing the activator protein-1 (AP-1) transcription factor. Interestingly, the inhibition of PI3K/Akt and MAPK signaling caused an LOX suppression which was not rescued by TGF- $\beta$ over-stimulation, suggesting that PI3K/Akt and MAPK effects on LOX go beyond the upregulation of TGF$\beta$. Similarly, PI3K inhibition also abrogated TGF- $\beta$-induced upregulation of BMP-1 and collagen [23].

Taken together, these findings suggest that TGF- $\beta$ orchestrates the organization of the ECM by coordinate transcriptional regulation of LOX and other functionally related proteins. Such process, however, depends on a complex integration of signals; in fact, TGF- $\beta$-induced LOX upregulation requires integration of the Smad-dependent pathway 
with PI3K/Akt and MAPK signaling. Similarly, a PI3K/ Akt mechanism has been shown to mediate TGF- $\beta$-induced upregulation of collagen and BMP-1 [23, 24].

Smad3 is the main responsible for TGF- $\beta$-induced activation of Akt (Smad3 inhibitor SIS3 reduces Akt phosphorylation significantly, although not entirely). While Smad3 increases Akt phosphorylation with a PI3K-dependent mechanism (PI3K inhibitor Wortmannin abrogates the effect), PI3K in return increases Smad3 phosphorylation [23, 25]. This positive feedback loop between Smad3 and PI3K can amplify TGF- $\beta$-driven LOX expression by increasing Smad3 phosphorylation and Akt downstream signaling and represents a relevant mechanism of integration between TGF- $\beta$ and PI3K/Akt signaling.

BMP-1 is the primary activator of at least two LOX family members (LOX and LOXL-1). BMP-1 also cleaves the latent TGF- $\beta$-binding protein (LTBP), thus liberating the small latent complex (SLC) from the ECM. The SLC released in the ECM is processed by the matrix metalloproteinase-2 (MMP-2), which removes the latency-associated protein (LAP), this way generating the active form of TGF- $\beta$ [26]. As TGF- $\beta$ upregulates both LOX and BMP-1, and the latter activates both LOX and TGF- $\beta$, the positive feedback loop between TGF- $\beta$ activation and BMP-1 upregulation also drives LOX upregulation and activation. At the same time, LOX-induced collagen cross-linking increases the ECM stiffness which (as discussed later) also produce mechanical activation of TGF- $\beta$, further fueling the process.

LOX, having a hypoxia-responsive element (HRE) in its promoter, is highly upregulated by the hypoxia-inducible factor-1 (HIF-1), which in turn is increased by LOX enzymatic activity. LOX activity, and in particular its byproduct $\mathrm{H}_{2} \mathrm{O}_{2}$, was shown to activate PI3K/Akt pathway by the increased phosphorylation of 3-phosphoinositide-dependent protein kinase-1 (PDPK-1) and Akt, this way increasing HIF- $1 \alpha$ expression at the translational level. No concomitant upregulation at transcriptional level or HIF-1 $\alpha$ stabilization was, however, observed [27]. Importantly, Akt/mTOR (Protein kinase B/Mammalian target of rapamycin) and Akt/ NF-kB pathways are known to increase HIF- $1 \alpha$ expression at the translational and transcriptional levels, respectively [28, 29]. A complex positive feedback loop, therefore, amplifies the signal: active Akt increases HIF-1-dependent LOX expression, while LOX activity, in turn, feeds back Akt activation. LOX, LOXL-2, and LOXL-4 are under direct HIF-1 transcriptional control [27, 30-32]. The Notch pathway and the tumor suppressor LKB1 (Liver kinase B1) also participate to HIF-1-dependent LOX regulation; the former enhances HIF-1 recruitment to the LOX HRE, causing LOX upregulation, while the latter, blocking mTOR/HIF-1 axis, downregulates LOX expression [33, 34].

MAPK signaling is a critical TGF- $\beta$ non-canonical (i.e., Smad-independent) pathway; TGF $\beta$ RI engages TRAF6
(TNF receptor associated factor 6) to activate TAK1 (TGF$\beta$-activated kinase 1 ) which, via different MAPK kinases (MKKs), leads in turn to the activation of the stress-activated kinases c-Jun N-terminal kinase (JNK) and p38 [25, $35,36]$. TGF $\beta R I$ is also able to activate RAS, which in turn activates JNK and the extracellular signal-regulated protein kinase (ERK) [37, 38]. MAPK activation, either secondary to TGF- $\beta$ non-canonical pathway or different mechanisms (e.g., hyperactive RAS, NF-kB stimulation, cytokines, and growth factors production), has a fundamental impact on TGF- $\beta$ signaling. Besides the direct effects on the oncogenes c-Myc and AP-1, MAPKs are also able to lead to non-canonical phosphorylation of Smad2 and Smad3, interfering with the TGF- $\beta$ canonical pathway. In the canonical TGF- $\beta$ signaling, TGF $\beta$ RI causes serine residues phosphorylation at the C terminus of Smad2 and Smad3 (pSmad2C and pSmad3C). On the other hand, MAPKs - as well as other non-canonical pathways, e.g., RhoA/ROCK (Ras homolog family member A/Rho-associated protein kinase) [39]—activate Smad2 and Smad3 by non-canonical phosphorylation of serine and threonine residues in the middle linker region $(\mathrm{pSmad} 2 \mathrm{~L}$ and pSmad3L) [20, 39-42].

Several studies have shown the association between particular Smad phospho-isoforms (p-isoforms) and specific types of signal [40, 43, 44].

pSmad3C and pSmad2C canonical p-isoforms, prevalent in homeostatic conditions in epithelial cells, transmit a cytostatic signal by c-Myc down-regulation and induction of cyclin-dependent kinases' (CDKs') inhibitors [45].

The non-canonical p-isoforms pSmad2L/C and pSmad3L/C - produced intranuclearly by CDKs-dependent phosphorylation of pSmad2C and pSmad3C, following MAPKs activation and c-Myc upregulation-transmit a transient mitogenic and fibrogenic signal inducing proliferation in the epithelial cells and activation and ECM deposition in mesenchymal cells.

In the presence of sustained MAPK activation, the noncanonical p-isoforms $\mathrm{pSmad} 3 \mathrm{~L}$ and a cytoplasmically produced form of $\mathrm{pSmad} 2 \mathrm{~L} / \mathrm{C}$ are produced constitutively. pSmad3L transmits a sustained mitogenic and fibrogenic signal by c-Myc upregulation inducing proliferation in the epithelial cells and activation and ECM deposition in mesenchymal cells $[39,45,46]$. pSmad2L/C is produced in the cytoplasm by TGF $\beta$ RI-mediated phosphorylation of the cytoplasmically retained pSmad2L. The phosphorylation of $\mathrm{pSmad} 2 \mathrm{~L}$ to $\mathrm{pSmad} 2 \mathrm{~L} / \mathrm{C}$ enables the nuclear translocation and the transmission of a sustained invasive and fibrogenic signal leading to upregulation of plasminogen activator inhibitor-1 (PAI-1) and MMP-9 [40, 43]. PAI-1 increases the ECM deposition and modifies the degree of cellular adhesion contributing to cell migration [47]. MMPs enhance cell invasion through the ECM proteins' degradation, which 
causes the release of active cleavage fragments and the opening of spaces, where cells can invade [40].

It is likely that different non-canonical signalings, from both non-Smad pathways and non-canonical Smad p-isoforms, integrate each other, and work synergistically to produce proliferative, invasive, and fibrogenic signals [45, 48].

The effects of non-canonical signaling on the activity of LOXs, to our knowledge, have not been studied. We can speculate that different types of Smad p-isoforms and TGF- $\beta$ signals influence differently the expression and activation of LOXs. It is plausible, for example, that a fibrogenic signal might be able to enhance greatly the activity of LOXs, while a cytostatic signal, on the other end, is likely to increase their activity to a smaller extent, if at all.

TGF- $\beta$ is often dysregulated in cancer. The shift from canonical to non-canonical TGF- $\beta$ signaling (discussed above) represents a significant mechanism of dysregulation. Other mechanisms, which typically increase in frequency with the tumor progression, include inactivating mutations of signaling cascade and decreased expression of TGF $\beta$ RI or TGF $\beta$ RII [49-51]. Despite the progressive termination of its cytostatic/apoptotic signal, TGF- $\beta$ tends to be overexpressed in cancer, with a possible variability depending on the stage of evolution [52]. The autocrine production by neoplastic cells is often involved, but TGF- $\beta$ is also produced by activated fibroblasts, regulatory $\mathrm{T}$ cells, tumor-associated macrophages, and myeloid-derived suppressive cells, which are part of the TIME [53, 54].

Many reports indicate that one or more LOX family members are also over-expressed in invasive and metastatic cancers [30, 55-57]. The mechanisms of LOXs' overexpression in cancer, to our knowledge, have not been elucidated. Activated stromal cells recruited in the TME are likely involved; however, tumor cells might also contribute to the overexpression of LOXs. TGF- $\beta$ and LOXs need to be tightly regulated to maintain the ECM homeostasis in normal conditions, but neoplastic cells might evade the regulatory mechanisms and produce LOXs constitutively (Fig. 1). In any case, as TGF- $\beta$ is often over-expressed and dysregulated in cancer, the increase of LOXs is likely, at least in part, TGF- $\beta$ driven. TGF- $\beta$ orchestrates the organization of the ECM and increases the expression of LOXs in normal conditions; therefore, it is plausible that TGF- $\beta$ dysregulation might associate with the overexpression of LOXs, and that their increased activity might be critical for the reorganization of the ECM and the establishment and maturation of the TIME.

In normal conditions, TGF- $\beta$ increases the expression of LOX and LOX, in turn, acts in a negative feedback to downregulate TGF- $\beta[58,59]$. It has been shown a dose-dependent binding between LOX and TGF- $\beta$, with the binding sites situated in the mature forms (as both full length and mature forms of LOX and TGF- $\beta$ can bind). Such

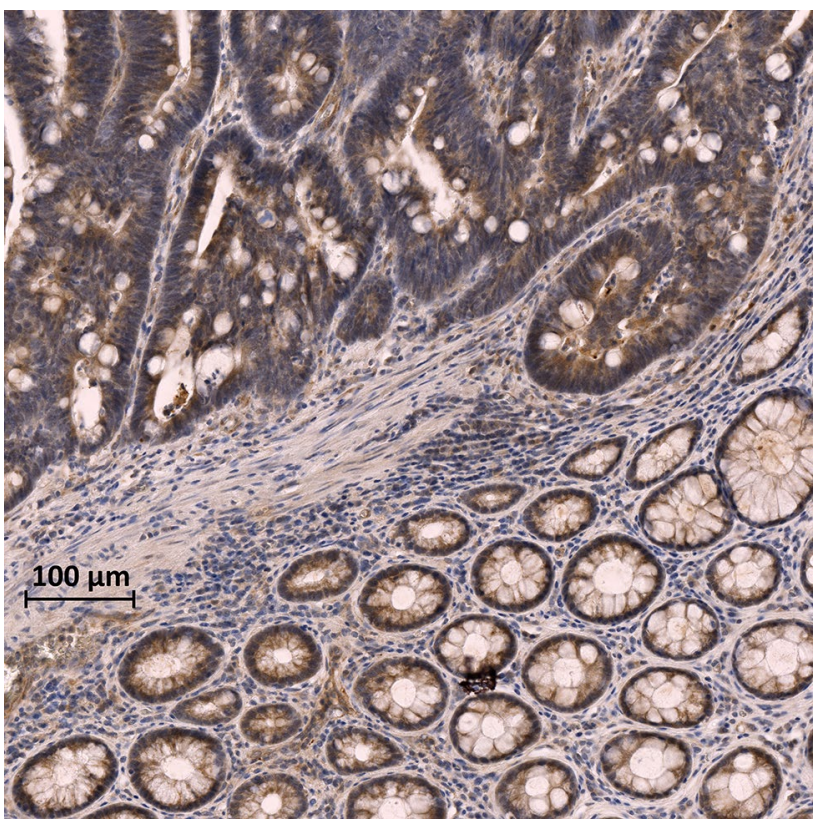

Fig. 1 LOXL-2 expression in AOM-induced rat colon cancer. Large positivity to LOXL-2 expression in the tumor tissue (upper part of the image) in comparison with the non-neoplastic mucosa (lower part of the image). Phosphatase anti-phosphatase immunohistochemistry with anti-LOXL-2 primary antibodies developed with DAB (brown color). $A O M$ azoxymethane, $D A B$ 3,3'-diaminobenzidine

interaction, localized in the ECM, is associated with suppression of Smad3 phosphorylation; the effect is rescued by beta-aminopropionitrile (BAPN), but is unaffected by catalase, suggesting that LOX direct enzymatic activity, rather than its byproduct $\mathrm{H}_{2} \mathrm{O}_{2}$, suppresses the TGF- $\beta$ signaling. Given LOX preference for basic substrates with $\mathrm{pI}>8$, it is thought that the mature TGF- $\beta$ molecule is targeted at the basic lysine-rich $\mathrm{C}$ terminus, and inactivated by oxidative deamination of lysine residues $[58,60]$.

In vivo experiments with $\mathrm{LOX}^{-1-}$ knock-out mice showed significant upregulation $(\sim 30 \%)$ of some TGF- $\beta$ target genes: SerpinE1 (encoding for PAI-1), CTGF (Connective Tissue Growth Factor), and Col1a2 (Collagen type I alpha 2 chain), confirming that LOX modulates TGF- $\beta$ signaling [59].

Recently, it has been shown that active LOX binds to the high temperature requirement A serine peptidase-1 (HTRA1), which is a secreted trimeric protease able to degrade TGF- $\beta$ [61-63]. LOX enzymatic activity induces HTRA1 higher order multimerization, which is required for its activation $[61,64]$.

LOX activity, therefore, seems able to promote TGF- $\beta$ degradation both directly, by oxidative deamination at the $\mathrm{C}$ terminus of TGF- $\beta$, and indirectly, by the activation of the high-temperature requirement $\mathrm{A}$ serine peptidase 1 (HTRA1). 
Myofibroblast contraction generates mechanical stress on the ECM, including stretching of the large latent complex (LLC), with the release of TGF- $\beta$ from LAP. The LLC is anchored to the ECM through the LTBP, while LAP binds to the myofibroblast through the extracellular domain of transmembrane proteins, i.e., integrins. Integrins intracellular domain binds to $\alpha$-SMA ( $\alpha$-smooth muscle actin) positive stress fibers, which are part of the myofibroblasts cytoskeleton. As a result of $\alpha-\mathrm{SMA} / \mathrm{myosin}$ interaction, the myofibroblasts contract, and the mechanical tension is propagated from the stress fibers to the LAP via the integrin bound. The entity of LLC stretching and of TGF- $\beta$ release increases with the stiffening of the ECM; in fact, it is required an ECM which resists the myofibroblast contraction to cause efficient LLC stretching $[18,19,65]$. While there is evidence of LOX acting in a negative feedback loop to promote TGF- $\beta$ degradation, on the other hand, LOX family members, as the primary regulators of the ECM maturation and stiffening, can increase the release of active TGF- $\beta$. We can hypothesize that the negative feedback exerted by LOXs is effective in normal conditions, but as dysregulation of TGF- $\beta$-signaling manifests in tumor tissue, an increase in ECM deposition and LOXs also occurs; as a consequence, the ECM stiffness also increases leading to additional release of TGF- $\beta$ from the extracellular deposit and further dysregulation, thus sustaining a vicious circle. In normal conditions, the balance among TGF- $\beta$ signaling, ECM deposition, and LOXmediated collagen cross-linking must be tightly regulated to maintain the tissue homeostasis. However, these interactions can be differently affected by the TME at different steps of its evolution (Fig. 2).

Other described transcription factors regulating LOX at the promoter level includes GATA-binding protein 3 (GATA-3) — which is also associated with T-helper 2 polarization-and the pro-survival transcription factor forkhead box M1b (FoxM1b), often over-expressed in cancer. GATA-3 suppresses LOX through the promoter methylation, while FoxM1b enhances its expression by the direct promoter binding [66, 67].

The above discussion highlights the importance of chronic inflammation in increasing the activity of LOXs. In fact, TGF- $\beta$ signaling, NF-kB activation (secondary to oxidative stress, growth factors, and inflammatory cytokines such as TNF- $\alpha$ and IL-1), MAPK activation, and HIF- $1 \alpha$ upregulation/stabilization are all stress and inflammation response mechanisms which are engaged in extensive cross-talking with LOXs. Given the increased level of one or another LOX family member in many types of cancer, it is strongly suggested a link between inflammation, LOXs, and cancer development.

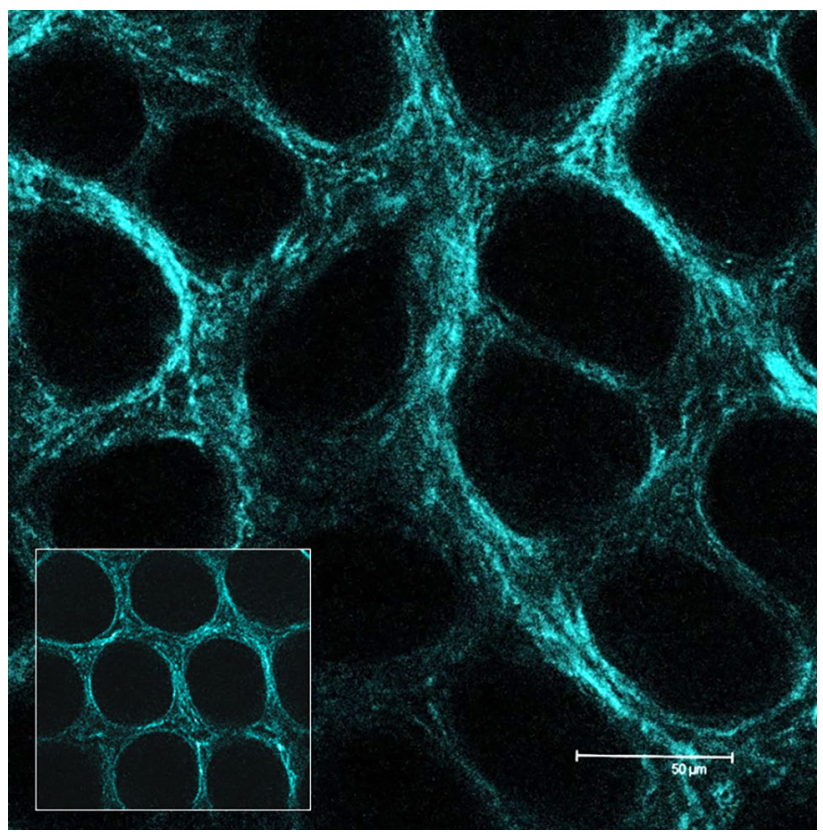

Fig. 2 Collagen scaffold structure in the rat colon mucosa. Evidence of increased density and initial alteration of the general architecture symmetry at 1 month after induction of carcinogenesis by AOM. In the square: aspect of the colon mucosa collagen scaffold in healthy rat. 2-photon laser scanning confocal imaging, SHG, $\times 63$ original magnification. AOM azoxymethane, $S H G$ second harmonic generation

\section{LOXs and the TME}

Most of the studies on LOXs have focused on LOX and, more recently, on LOXL-2. As the enzymatic activity of LOX family members is thought to be similar, disentangling the differences among the different members has proved challenging and further researches are necessary. LOX-PP, the 162-amino-acid pro-peptide domain of proLOX, is considered an oncosuppressor, as it decreases the RAS oncogene signaling by the interaction with c-Raf and the $\mathrm{c}$-Raf chaperone Hsp70 to reduce MAPK/ERK activation [68-70]. Recently, recombinant LOX-PP has been shown to sensitize prostate cancer cells to apoptosis through the nuclear translocation and interaction with the nuclear DNA repair regulator MRE11 at DNA repair foci [71]. Despite this anti-tumor role documented for LOX-PP, and the reduced levels of some LOXs in a minority of cancers, the mature LOX, as well as other LOX family members, has a predominant pro-neoplastic activity. The LOXs increase in invasive and metastatic cancer, and their high expression is correlated with poor survival $[30,55-57]$. There is increasing evidence of the importance of LOXs in driving tumor growth and progression; in particular, many studies indicate that the HIF-1/LOXs' axis is a crucial mechanism in driving the tumor cell proliferation, the epithelial-mesenchymal 
transition (EMT), the formation of pre-metastatic niches, and the cancer cells migration and invasion [27, 56, 72-75].

It is not clear how a family of enzymes acting on the ECM can induce intracellular signaling to drive tumor progression. The increase in stiffness of the ECM, promoting focal adhesions formation and integrins activation, is the most studied mechanism. The $\beta$-integrins (INT $\beta$ ) - specifically INT $\beta 1$, INT $\beta 3$, and INT $\beta 4$ - have an essential role as mechanosensor and transducers of the ECM stiffness. INT $\beta$ activation leads to SRC kinase recruitment and SRC-dependent phosphorylation of a focal adhesion kinase (FAK) [73, 76, 77]. Phosphorylated FAK can activate several signaling pathways, including RAS/MAPK and Rho/ ROCK, the latter leading to activation/remodeling of the actin cytoskeleton and the acquisition of a migratory phenotype [78]. Active FAK can enhance ErbB2-induced triggering of PI3K/Akt signaling in mammary epithelial cells stimulated by the epidermal growth factor (EGF); however, it is not able to increase Akt directly in unstimulated cells [73]. The mechanisms behind such enhancing effect have not been elucidated; we can speculate that FAK activation might increase the expression or the surface retention of ErbB2, and possibly other related receptors of the EGFR family. It is not known if other receptors are also enhanced by FAK; if so, the ECM stiffness could modulate an even broader range of signals.

Recently, a mechanism of surface "trapping" of the EGFR has been shown to depend on LOX-mediated degradation of TGF- $\beta$ and to be instead independent of the ECM stiffness and SRC phosphorylation. LOX-mediated degradation of TGF- $\beta$ (previously reviewed) reduces the suppressive effect of TGF- $\beta$ signaling on matrilin2 (MATN2), a protein containing ten EGF-like domain. Consequently, MATN2 accumulates and through its EGF-like domains binds EGFR, causing the surface "trapping" of the receptor, i.e., its surface retention. The resulting increased that the availability of EGFR boosts the EGF signaling leading to Akt activation, which in turn drives cell proliferation [61].

LOXs can be produced by different cell types, including epithelial cells, endothelial cells, and activated fibroblasts.

Tumor-secreted LOXL-2 has been described to activate stroma fibroblasts (to $\alpha$-SMA + myofibroblasts) and vascular smooth muscle cells through the $\mathrm{H}_{2} \mathrm{O}_{2}$-mediated activation of FAK/SRC and ErbB2/Erk2 signaling [79, 80]. LOXL-2 has also been shown to promote fibroblast activation and invasion of the ECM through an INT $\beta 3$-dependent but SRCindependent activation of FAK/Akt signaling [81].

Activated stromal cells, in turn, produce LOXL-2 along with chemokines and growth factors such as VEGF, plateletderived growth factor (PDGF), and fibroblast growth factor (FGF). Therefore, tumor-secreted LOXs act in a positive feedback loop to activate stromal cells to produce further
LOXs and growth factors, thus driving the TME remodeling and the tumor progression [81].

It is noteworthy that in vitro experiments with LOXs inhibitors showed a prominent role of LOXL-2 versus LOX in tumor growth, collagen cross-linking, angiogenesis, and fibroblast activation [82]. LOXL-2 expression has also been linked to upregulation of tissue inhibitor of metalloproteinase-1 (TIMP-1) and MMP-9. TIMP-1 promotes resistance to apoptosis, cell proliferation, and metastasis through mechanisms which enhance FAK, Akt, and MAPK phosphorylation and are probably independent of the MMP inhibition [83].

Recently, the hydrogen peroxide-inducible clone-5 (Hic5 ) was found over-expressed in cancer-associated fibroblasts (CAFs), but not cancer cells. Hic-5 resulted necessary for the generation of a tumor-permissive microenvironment; in fact, the gene knock-out completely prevented the cancer development in an azoxymethane-induced colorectal cancer mice model. Cancer-related cytokines such as TGF- $\beta$, PDGF, IL-1 $\beta$, and stromal cell-derived factor-1 (SDF-1) were found able to induce fibroblast activation and acquisition of a CAF phenotype including Hic-5 high expression. In turn, Hic-5 accumulated inside the nucleus and induced LOX and type- 1 collagen expression. This evidence suggested that TGF- $\beta$, PDGF, IL- $1 \beta$, and SDF-1 induce a Hic5-rich CAF phenotype which drives the overexpression of LOX and collagen to increase the ECM stiffness and generate a tumor-permissive stroma [84].

During the EMT, immobile transformed cells lose their epithelial polarization and inter-cellular adhesion properties to acquire a migratory and invasive mesenchymal-like phenotype. Characteristic biomarkers of these functional modifications are the down-regulation of E-cadherin (a component of adherens junctions) and the upregulation of $\alpha$-SMA (a marker of cytoskeletal reorganization), vimentin, and $\mathrm{N}$-cadherin (mesenchymal markers). Many survival/proliferation signals are involved in EMT, including hypoxia, Akt/ Snail, WNT/ $\beta$-Catenin, Notch, and Smad/non-Smad TGF- $\beta$ signaling, regulating the expression of the so-called EMT transcription factors (EMT-TFs). One of the most studied EMT-TFs is Snail, known for repressing E-cadherin directly at the promoter level [85]. LOXL-2 and LOXL-3 have been shown to stabilize Snail-1 (this way downregulating the E-cadherin) through a protective modification of Snail-1 on the N-terminal SNAG domain. The modified domain cannot be phosphorylated by the glycogen synthase kinase- 3 beta (GSK3B); therefore, Snail-1 ubiquitination and targeting for proteasomal degradation are prevented [86]. LOXL-2 has also been reported to interact with E47 EMT-TF, cooperating in the repression of the E-cadherin promoter [87]. LOXs are often critically involved in the EMT: either by direct upregulation of EMT-TFs, or indirectly by an upstream process, or by complex combinations of them. LOX-mediated 
stiffening of the ECM leads to the release of active TGF- $\beta$ as well as activation of FAK/SRC, both of them contributing to the loss of adhesion and acquisition of a motile phenotype [78]. LOXs enhance Snail-1 activity partly by direct Snail-1 stabilization and partly by upregulation at translational level of HIF-1, which in turn promotes Snail-1 activation, besides upregulating other EMT-TFs such as ZEB1 [31, 88, 89]. FoxM1b drives EMT by Akt-mediated block of GSK3B and consequent Snail-1 stabilization; at the same time, it upregulates at promoter level LOX and LOXL-2, which also stabilize Snail-1 and activate Akt, besides driving EMT by the increase in stiffness of the ECM [67].

Hypoxia-driven production and secretion of LOXs are deemed a fundamental component of the tumor secretome leading to the formation at secondary sites of permissive niches, where the environment is prepared for the metastatic colonization (pre-metastatic niche). In this process, LOX-dependent cross-linking of type IV collagen in the basement membrane provides the signal for bone marrow $\mathrm{CD} 11 \mathrm{~b}+$ myeloid cells' recruitment and chemotaxis $[32$, 90].

LOXL-2 activity is regarded as essential in the ECM remodeling required for the neo-angiogenesis, as it regulates the sprouting of neo-vessel through its accumulation in the endothelial cells and the assembling of type IV collagen in their basement membrane [16]. Both LOXs and VEGF are hypoxia signature genes, suggesting their cooperative role under HIF control.

\section{Final remarks and conclusions}

Experimental data have focused prevalently on LOX, and more recently, to a lesser extent, on LOXL-2. LOX family members are likely to present a partially overlapping activity, but also distinct functions, specific for each member and types of tissues and physiopathological conditions. Such a difference in activities is also documented by recent publications. The involvement of one or more members of LOXs (in the active form or as the pro-peptide) was evaluated in different cancers and conditions: experimental ornithine decarboxylase- and RAS-transformed mouse fibroblasts and human melanoma cells, renal and bladder, and gastric cancers, respectively [91-93]. LOXs showed variability of expression during tumor development, with the possibility of exerting either promotion or even inhibition effects depending on the type of LOX expressed, the tumor type, and the microenvironment. In a prostate cancer model, BAPN-induced inhibition of LOXs resulted in tumor suppressive effects when treatment was initiated before the tumor implantation and tumor-promoting effects when treatment was initiated after the tumor establishment [94]. These findings strongly suggest the importance of studying LOXs in the specific microenvironment of the tissue, where the tumor arises, according to the TME modifications during its establishment and evolution.

Until now, the research of inhibitors of LOXs has principally focused on LTQ-directed molecules, which bind the LTQ cofactor irreversibly inhibiting their enzymatic activity. These molecules are usually primary amines, like in the case of BAPN, and inhibit LOXs specifically (unlike the copper chelators, e.g., disulfiram); however, they are frequently not selective for a specific LOX family member [95, 96]. BAPN, the prototypic and most utilized inhibitor of LOXs, is usually considered a pan-inhibitor, although several conflicting studies report a negligible activity of BAPN on one or another LOX family member; therefore, it is necessary to exercise caution when interpreting the effects of non-selective inhibitors such as BAPN [97]. The development of selective inhibitors would help significantly to disentangle the effects of one LOX family member from another, but the process is still hindered by the unavailability of the crystal structure for each of these molecules. Cell-permeable inhibitors would also be beneficial, allowing to discriminate between intracellular and extracellular functions of LOXs.

Recently, a monoclonal antibody has been employed successfully in the selective inhibition of LOXL-2. This approach proved effective in contrasting the development of the TME in in vivo cancer models, reducing fibroblast activation, growth factors production, and TGF- $\beta$ signaling. It also significantly reduced the tumor burden, outperforming the treatment with BAPN [82].

The unavailability of valuable genetically modified animal models for each LOX family member is another limit for these studies. In the case of LOX, the production of gene knock-out animals resulted in $100 \%$ lethality (end of gestation or perinatal period), associated with severe cardiovascular malformations $[4,14,98]$. LOXL-2 knock-out animals also suffer $50 \%$ perinatal mortality and a high incidence of severe cardiovascular defects [99]. These catastrophic effects highlight the fundamental role of LOXs in the tissue morphogenesis and stroma maturation.

A majority of studies have focused on the effects of LOXs on the tumor progression and development of metastatic disease. However, there is also strong evidence supporting a significant role of LOXs in the transformation of normal epithelial cells, in the accelerated tumor development and the induction of invasion of the premalignant epithelium $[61,73,79]$.

The networking with the TGF- $\beta$ signaling is also intriguing for the possible links between these molecules, the tumor structure development, and the immune microenvironment progressive organization during the tumorigenesis and, later on, the formation of the metastatic niches.

The recent discoveries of several new substrates and alternative catalytic and non-catalytic functions of LOXs (e.g., as 
transcription or co-transcription factors) show a complex and multifaceted involvement in the biology and immunology of the TME. Thus, we believe that a better understanding of the structure and function of these molecules will prove extremely valuable to further enlighten the tumor-immunity interactions and to design novel anti-tumor strategies targeting the TIME development and evolution.

Acknowledgements The authors wish to thank the Institute of Microbiology of the Czech Academy of Sciences, Czech Republic, for supporting this work by the institutional Grant no. RVO 61388971. They also would like to thank: Dr. Peter Makovicky, Institute of Molecular Genetics of the Czech Academy of Sciences, Prague, Czech Republic, for the technical contribution in the preparation of histological samples; Dr. Dmitry Stakheev, Institute of Microbiology of the Czech Academy of Sciences, Prague, Czech Republic, for the technical contribution in the preparation of confocal microscopy images.

Author contributions The authors equally participated in conceiving the paper and in performing the literature search and the analysis and organization of the presented data. Vannucci performed the critical revision of the work.

Funding This study was supported by the donations of Generali/Czech Insurance Foundation (Czech Republic) and UniCredit Bank Czech Republic.

\section{Compliance with ethical standards}

Conflict of interest The authors declare no conflicts of interest.

Open Access This article is distributed under the terms of the Creative Commons Attribution 4.0 International License (http://creativeco mmons.org/licenses/by/4.0/), which permits unrestricted use, distribution, and reproduction in any medium, provided you give appropriate credit to the original author(s) and the source, provide a link to the Creative Commons license, and indicate if changes were made.

\section{References}

1. Csiszar K (2001) Lysyl oxidases: a novel multifunctional amine oxidase family. Prog Nucleic Acid Res Mol Biol 70:1-32

2. Krebs CJ, Krawetz SA (1993) Lysyl oxidase copper-talon complex: a model. Biochim Biophys Acta 1202(1):7-12. https://doi. org/10.1016/0167-4838(93)90056-w

3. Wang SX, Mure M, Medzihradszky KF, Burlingame AL, Brown DE, Dooley DM, Smith AJ, Kagan HM, Klinman JP (1996) A crosslinked cofactor in lysyl oxidase: redox function for amino acid side chains. Science 273(5278):1078-1084. https://doi. org/10.1126/science.273.5278.1078

4. Maki JM, Rasanen J, Tikkanen H, Sormunen R, Makikallio K, Kivirikko KI, Soininen R (2002) Inactivation of the lysyl oxidase gene Lox leads to aortic aneurysms, cardiovascular dysfunction, and perinatal death in mice. Circulation 106(19):2503-2509. https ://doi.org/10.1161/01.cir.0000038109.84500.1e

5. Ge G, Greenspan DS (2006) Developmental roles of the BMP1/ TLD metalloproteinases. Birth Defects Res C Embryo Today 78(1):47-68. https://doi.org/10.1002/bdrc.20060
6. Uzel MI, Scott IC, Babakhanlou-Chase H, Palamakumbura AH, Pappano WN, Hong HH, Greenspan DS, Trackman PC (2001) Multiple bone morphogenetic protein 1-related mammalian metalloproteinases process pro-lysyl oxidase at the correct physiological site and control lysyl oxidase activation in mouse embryo fibroblast cultures. J Biol Chem 276(25):22537-22543. https:// doi.org/10.1074/jbc.M102352200

7. Lucero HA, Kagan HM (2006) Lysyl oxidase: an oxidative enzyme and effector of cell function. Cell Mol Life Sci 63(1920):2304-2316. https://doi.org/10.1007/s00018-006-6149-9

8. Borel A, Eichenberger D, Farjanel J, Kessler E, Gleyzal C, Hulmes DJ, Sommer P, Font B (2001) Lysyl oxidase-like protein from bovine aorta. Isolation and maturation to an active form by bone morphogenetic protein-1. J Biol Chem 276(52):48944-48949. https://doi.org/10.1074/jbc.m109499200

9. Rodriguez HM, Vaysberg M, Mikels A, McCauley S, Velayo AC, Garcia C, Smith V (2010) Modulation of lysyl oxidase-like 2 enzymatic activity by an allosteric antibody inhibitor. J Biol Chem 285(27):20964-20974. https://doi.org/10.1074/jbc.M109.094136

10. Lopez-Jimenez AJ, Basak T, Vanacore RM (2017) Proteolytic processing of lysyl oxidase-like-2 in the extracellular matrix is required for crosslinking of basement membrane collagen IV. J Biol Chem 292(41):16970-16982. https://doi.org/10.1074/jbc. M117.798603

11. Vadasz Z, Kessler O, Akiri G, Gengrinovitch S, Kagan HM, Baruch Y, Izhak OB, Neufeld G (2005) Abnormal deposition of collagen around hepatocytes in Wilson's disease is associated with hepatocyte specific expression of lysyl oxidase and lysyl oxidase like protein-2. J Hepatol 43(3):499-507. https://doi.org/10.1016/j. jhep.2005.02.052

12. Grau-Bove X, Ruiz-Trillo I, Rodriguez-Pascual F (2015) Origin and evolution of lysyl oxidases. Sci Rep 5:10568. https://doi. org/10.1038/srep10568

13. Herchenhan A, Uhlenbrock F, Eliasson P, Weis M, Eyre D, Kadler KE, Magnusson SP, Kjaer M (2015) Lysyl oxidase activity is required for ordered collagen fibrillogenesis by tendon cells. J Biol Chem 290(26):16440-16450. https://doi.org/10.1074/jbc. M115.641670

14. Maki JM, Sormunen R, Lippo S, Kaarteenaho-Wiik R, Soininen R, Myllyharju J (2005) Lysyl oxidase is essential for normal development and function of the respiratory system and for the integrity of elastic and collagen fibers in various tissues. Am J Pathol 167(4):927-936. https://doi.org/10.1016/S0002-9440(10)61183-2

15. Liu X, Zhao Y, Gao J, Pawlyk B, Starcher B, Spencer JA, Yanagisawa H, Zuo J, Li T (2004) Elastic fiber homeostasis requires lysyl oxidase-like 1 protein. Nat Genet 36(2):178-182. https:// doi.org/10.1038/ng 1297

16. Bignon M, Pichol-Thievend C, Hardouin J, Malbouyres M, Brechot N, Nasciutti L, Barret A, Teillon J, Guillon E, Etienne E, Caron M, Joubert-Caron R, Monnot C, Ruggiero F, Muller L, Germain S (2011) Lysyl oxidase-like protein-2 regulates sprouting angiogenesis and type IV collagen assembly in the endothelial basement membrane. Blood 118(14):3979-3989. https://doi. org/10.1182/blood-2010-10-313296

17. Martinez VG, Moestrup SK, Holmskov U, Mollenhauer J, Lozano F (2011) The conserved scavenger receptor cysteine-rich superfamily in therapy and diagnosis. Pharmacol Rev 63(4):967-1000. https://doi.org/10.1124/pr.111.004523

18. Vannucci L (2015) Stroma as an active player in the development of the tumor microenvironment. Cancer Microenviron 8(3):159_ 166. https://doi.org/10.1007/s12307-014-0150-x

19. Varol C, Sagi I (2018) Phagocyte-extracellular matrix crosstalk empowers tumor development and dissemination. FEBS J 285(4):734-751. https://doi.org/10.1111/febs.14317

20. Sekimoto G, Matsuzaki K, Yoshida K, Mori S, Murata M, Seki T, Matsui H, Fujisawa J, Okazaki K (2007) 
Reversible Smad-dependent signaling between tumor suppression and oncogenesis. Cancer Res 67(11):5090-5096. https://doi. org/10.1158/0008-5472.CAN-06-4629

21. Lehmann K, Janda E, Pierreux CE, Rytomaa M, Schulze A, McMahon M, Hill CS, Beug H, Downward J (2000) Raf induces TGFbeta production while blocking its apoptotic but not invasive responses: a mechanism leading to increased malignancy in epithelial cells. Genes Dev 14(20):2610-2622. https://doi. org/10.1101/gad.181700

22. Salazar VS, Zarkadis N, Huang L, Norris J, Grimston SK, Mbalaviele G, Civitelli R (2013) Embryonic ablation of osteoblast Smad4 interrupts matrix synthesis in response to canonical Wnt signaling and causes an osteogenesis-imperfecta-like phenotype. $\mathrm{J}$ Cell Sci 126(Pt 21):4974-4984. https://doi.org/10.1242/jcs.13195

23. Voloshenyuk TG, Landesman ES, Khoutorova E, Hart AD, Gardner JD (2011) Induction of cardiac fibroblast lysyl oxidase by TGF-beta1 requires PI3K/Akt, Smad3, and MAPK signaling. Cytokine 55(1):90-97. https://doi.org/10.1016/j.cyto.2011.03.024

24. Ricupero DA, Poliks CF, Rishikof DC, Cuttle KA, Kuang PP, Goldstein RH (2001) Phosphatidylinositol 3-kinase-dependent stabilization of alpha1(I) collagen mRNA in human lung fibroblasts. Am J Physiol Cell Physiol 281(1):C99-C105. https://doi. org/10.1152/ajpcell.2001.281.1.C99

25. Voloshenyuk TG, Hart AD, Khoutorova E, Gardner JD (2011) TNF-alpha increases cardiac fibroblast lysyl oxidase expression through TGF-beta and PI3Kinase signaling pathways. Biochem Biophys Res Commun 413(2):370-375. https://doi.org/10.1016/j. bbrc.2011.08.109

26. Ge G, Greenspan DS (2006) BMP1 controls TGFbeta1 activation via cleavage of latent TGFbeta-binding protein. J Cell Biol 175(1):111-120. https://doi.org/10.1083/jcb.200606058

27. Pez F, Dayan F, Durivault J, Kaniewski B, Aimond G, Le Provost GS, Deux B, Clezardin P, Sommer P, Pouyssegur J, Reynaud C (2011) The HIF-1-inducible lysyl oxidase activates HIF-1 via the Akt pathway in a positive regulation loop and synergizes with HIF-1 in promoting tumor cell growth. Cancer Res 71(5):16471657. https://doi.org/10.1158/0008-5472.CAN-10-1516

28. Choi YK, Kim CK, Lee H, Jeoung D, Ha KS, Kwon YG, Kim KW, Kim YM (2010) Carbon monoxide promotes VEGF expression by increasing HIF-1alpha protein level via two distinct mechanisms, translational activation and stabilization of HIF-1alpha protein. J Biol Chem 285(42):32116-32125. https://doi.org/10.1074/jbc. M110.131284

29. Gao N, Ding M, Zheng JZ, Zhang Z, Leonard SS, Liu KJ, Shi X, Jiang BH (2002) Vanadate-induced expression of hypoxiainducible factor 1 alpha and vascular endothelial growth factor through phosphatidylinositol 3-kinase/Akt pathway and reactive oxygen species. J Biol Chem 277(35):31963-31971. https://doi. org/10.1074/jbc.M200082200

30. Erler JT, Bennewith KL, Nicolau M, Dornhofer N, Kong C, Le QT, Chi JT, Jeffrey SS, Giaccia AJ (2006) Lysyl oxidase is essential for hypoxia-induced metastasis. Nature 440(7088):1222-1226. https://doi.org/10.1038/nature04695

31. Schietke R, Warnecke C, Wacker I, Schodel J, Mole DR, Campean V, Amann K, Goppelt-Struebe M, Behrens J, Eckardt KU, Wiesener MS (2010) The lysyl oxidases LOX and LOXL2 are necessary and sufficient to repress E-cadherin in hypoxia: insights into cellular transformation processes mediated by HIF1. J Biol Chem 285(9):6658-6669. https://doi.org/10.1074/jbc. M109.042424

32. Wong CC, Gilkes DM, Zhang H, Chen J, Wei H, Chaturvedi P, Fraley SI, Wong CM, Khoo US, Ng IO, Wirtz D, Semenza GL (2011) Hypoxia-inducible factor 1 is a master regulator of breast cancer metastatic niche formation. Proc Natl Acad Sci USA 108(39):16369-16374. https://doi.org/10.1073/pnas.1113483108
33. Sahlgren C, Gustafsson MV, Jin S, Poellinger L, Lendahl U (2008) Notch signaling mediates hypoxia-induced tumor cell migration and invasion. Proc Natl Acad Sci USA 105(17):6392-6397. https ://doi.org/10.1073/pnas.0802047105

34. Gao Y, Xiao Q, Ma H, Li L, Liu J, Feng Y, Fang Z, Wu J, Han X, Zhang J, Sun Y, Wu G, Padera R, Chen H, Wong KK, Ge G, Ji H (2010) LKB1 inhibits lung cancer progression through lysyl oxidase and extracellular matrix remodeling. Proc Natl Acad Sci USA 107(44):18892-18897. https://doi.org/10.1073/pnas.10049 52107

35. Sorrentino A, Thakur N, Grimsby S, Marcusson A, von Bulow V, Schuster N, Zhang S, Heldin CH, Landstrom M (2008) The type I TGF-beta receptor engages TRAF6 to activate TAK1 in a receptor kinase-independent manner. Nat Cell Biol 10(10):1199-1207. https://doi.org/10.1038/ncb1780

36. Yamashita M, Fatyol K, Jin C, Wang X, Liu Z, Zhang YE (2008) TRAF6 mediates Smad-independent activation of JNK and p38 by TGF-beta. Mol Cell 31(6):918-924. https://doi.org/10.1016/j. molcel.2008.09.002

37. Yamaguchi K, Shirakabe K, Shibuya H, Irie K, Oishi I, Ueno N, Taniguchi T, Nishida E, Matsumoto K (1995) Identification of a member of the MAPKKK family as a potential mediator of TGFbeta signal transduction. Science 270(5244):2008-2011. https:// doi.org/10.1126/science.270.5244.2008

38. Derijard B, Hibi M, Wu IH, Barrett T, Su B, Deng T, Karin M, Davis RJ (1994) JNK1: a protein kinase stimulated by UV light and Ha-Ras that binds and phosphorylates the c-Jun activation domain. Cell 76(6):1025-1037. https://doi.org/10.1016/00928674(94)90380-8

39. Browne JA, Liu X, Schnaper HW, Hayashida T (2013) Serine-204 in the linker region of Smad3 mediates the collagen-I response to TGF-beta in a cell phenotype-specific manner. Exp Cell Res 319(19):2928-2937. https://doi.org/10.1016/j.yexcr.2013.07.013

40. Matsuzaki K, Kitano C, Murata M, Sekimoto G, Yoshida K, Uemura Y, Seki T, Taketani S, Fujisawa J, Okazaki K (2009) Smad2 and Smad3 phosphorylated at both linker and $\mathrm{COOH}-$ terminal regions transmit malignant TGF-beta signal in later stages of human colorectal cancer. Cancer Res 69(13):5321-5330. https ://doi.org/10.1158/0008-5472.CAN-08-4203

41. Velden JL, Alcorn JF, Guala AS, Badura EC, Janssen-Heininger YM (2011) c-Jun N-terminal kinase 1 promotes transforming growth factor-beta1-induced epithelial-to-mesenchymal transition via control of linker phosphorylation and transcriptional activity of Smad3. Am J Respir Cell Mol Biol 44(4):571-581. https://doi. org/10.1165/rcmb.2009-0282OC

42. Suzuki R, Fukui T, Kishimoto M, Miyamoto S, Takahashi Y, Takeo M, Mitsuyama T, Sakaguchi Y, Uchida K, Nishio A, Okazaki K (2015) Smad2/3 linker phosphorylation is a possible marker of cancer stem cells and correlates with carcinogenesis in a mouse model of colitis-associated colorectal cancer. J Crohns Colitis 9(7):565-574. https://doi.org/10.1093/ecco-jcc/jjv073

43. Furukawa F, Matsuzaki K, Mori S, Tahashi Y, Yoshida K, Sugano Y, Yamagata H, Matsushita M, Seki T, Inagaki Y, Nishizawa M, Fujisawa J, Inoue K (2003) p38 MAPK mediates fibrogenic signal through Smad3 phosphorylation in rat myofibroblasts. Hepatology 38(4):879-889. https://doi.org/10.1053/jhep.2003.50384

44. Matsuzaki K (2011) Smad phosphoisoform signaling specificity: the right place at the right time. Carcinogenesis 32(11):15781588. https://doi.org/10.1093/carcin/bgr172

45. Yoshida K, Murata M, Yamaguchi T, Matsuzaki K (2014) TGF-beta/Smad signaling during hepatic fibro-carcinogenesis (review). Int J Oncol 45(4):1363-1371. https://doi.org/10.3892/ ijo.2014.2552

46. Yoshida K, Matsuzaki K, Mori S, Tahashi Y, Yamagata H, Furukawa F, Seki T, Nishizawa M, Fujisawa J, Okazaki K (2005) Transforming growth factor-beta and platelet-derived growth 
factor signal via c-Jun N-terminal kinase-dependent Smad2/3 phosphorylation in rat hepatic stellate cells after acute liver injury. Am J Pathol 166(4):1029-1039. https://doi.org/10.1016/s0002 -9440(10)62324-3

47. Hu PF, Chen H, Zhong W, Lin Y, Zhang X, Chen YX, Xie WF (2009) Adenovirus-mediated transfer of siRNA against PAI-1 mRNA ameliorates hepatic fibrosis in rats. J Hepatol 51(1):102113. https://doi.org/10.1016/j.jhep.2009.02.025

48. Zhang YE (2009) Non-Smad pathways in TGF-beta signaling. Cell Res 19(1):128-139. https://doi.org/10.1038/cr.2008.328

49. Markowitz S, Wang J, Myeroff L, Parsons R, Sun L, Lutterbaugh J, Fan RS, Zborowska E, Kinzler KW, Vogelstein B et al (1995) Inactivation of the type II TGF-beta receptor in colon cancer cells with microsatellite instability. Science 268(5215):1336-1338. https://doi.org/10.1126/science.7761852

50. Kim IY, Ahn HJ, Zelner DJ, Shaw JW, Lang S, Kato M, Oefelein MG, Miyazono K, Nemeth JA, Kozlowski JM, Lee C (1996) Loss of expression of transforming growth factor beta type I and type II receptors correlates with tumor grade in human prostate cancer tissues. Clin Cancer Res 2(8):1255-1261

51. Lu SL, Herrington H, Reh D, Weber S, Bornstein S, Wang D, Li AG, Tang CF, Siddiqui Y, Nord J, Andersen P, Corless CL, Wang XJ (2006) Loss of transforming growth factor-beta type II receptor promotes metastatic head-and-neck squamous cell carcinoma. Genes Dev 20(10):1331-1342. https://doi.org/10.1101/gad.14133 06

52. Gao J, Aksoy BA, Dogrusoz U, Dresdner G, Gross B, Sumer SO, Sun Y, Jacobsen A, Sinha R, Larsson E, Cerami E, Sander C, Schultz N (2013) Integrative analysis of complex cancer genomics and clinical profiles using the cBioPortal. Sci Signal 6(269):11. https://doi.org/10.1126/scisignal.2004088

53. Ghiringhelli F, Puig PE, Roux S, Parcellier A, Schmitt E, Solary E, Kroemer G, Martin F, Chauffert B, Zitvogel L (2005) Tumor cells convert immature myeloid dendritic cells into TGF-betasecreting cells inducing CD4+CD25+regulatory T cell proliferation. J Exp Med 202(7):919-929. https://doi.org/10.1084/ jem.20050463

54. Dumitriu IE, Dunbar DR, Howie SE, Sethi T, Gregory CD (2009) Human dendritic cells produce TGF-beta 1 under the influence of lung carcinoma cells and prime the differentiation of CD4+CD25+Foxp3+ regulatory T cells. J Immunol 182(5):27952807. https://doi.org/10.4049/jimmunol.0712671

55. Stewart GD, Gray K, Pennington CJ, Edwards DR, Riddick AC, Ross JA, Habib FK (2008) Analysis of hypoxia-associated gene expression in prostate cancer: lysyl oxidase and glucose transporter-1 expression correlate with Gleason score. Oncol Rep 20(6): 1561-1567

56. Miller BW, Morton JP, Pinese M, Saturno G, Jamieson NB, McGhee E, Timpson P, Leach J, McGarry L, Shanks E, Bailey P, Chang D, Oien K, Karim S, Au A, Steele C, Carter CR, McKay C, Anderson K, Evans TR, Marais R, Springer C, Biankin A, Erler JT, Sansom OJ (2015) Targeting the LOX/hypoxia axis reverses many of the features that make pancreatic cancer deadly: inhibition of LOX abrogates metastasis and enhances drug efficacy. EMBO Mol Med 7(8):1063-1076. https://doi.org/10.15252/ emmm.201404827

57. Wilgus ML, Borczuk AC, Stoopler M, Ginsburg M, Gorenstein L, Sonett JR, Powell CA (2011) Lysyl oxidase: a lung adenocarcinoma biomarker of invasion and survival. Cancer 117(10):21862191. https://doi.org/10.1002/cncr.25768

58. Atsawasuwan P, Mochida Y, Katafuchi M, Kaku M, Fong KS, Csiszar K, Yamauchi M (2008) Lysyl oxidase binds transforming growth factor-beta and regulates its signaling via amine oxidase activity. J Biol Chem 283(49):34229-34240. https://doi. org/10.1074/jbc.M803142200
59. Kutchuk L, Laitala A, Soueid-Bomgarten S, Shentzer P, Rosendahl AH, Eilot S, Grossman M, Sagi I, Sormunen R, Myllyharju J, Maki JM, Hasson P (2015) Muscle composition is regulated by a Lox-TGFbeta feedback loop. Development 142(5):983-993. https://doi.org/10.1242/dev.113449

60. Kagan HM, Williams MA, Williamson PR, Anderson JM (1984) Influence of sequence and charge on the specificity of lysyl oxidase toward protein and synthetic peptide substrates. J Biol Chem 259(18):11203-11207

61. Tang H, Leung L, Saturno G, Viros A, Smith D, Di Leva G, Morrison E, Niculescu-Duvaz D, Lopes F, Johnson L, Dhomen N, Springer C, Marais R (2017) Lysyl oxidase drives tumour progression by trapping EGF receptors at the cell surface. Nat Commun 8:14909. https://doi.org/10.1038/ncomms14909

62. Oka C, Tsujimoto R, Kajikawa M, Koshiba-Takeuchi K, Ina J, Yano M, Tsuchiya A, Ueta Y, Soma A, Kanda H, Matsumoto M, Kawaichi M (2004) HtrA1 serine protease inhibits signaling mediated by Tgfbeta family proteins. Development 131(5):1041-1053. https://doi.org/10.1242/dev.00999

63. Launay S, Maubert E, Lebeurrier N, Tennstaedt A, Campioni M, Docagne F, Gabriel C, Dauphinot L, Potier MC, Ehrmann M, Baldi A, Vivien D (2008) HtrA1-dependent proteolysis of TGF-beta controls both neuronal maturation and developmental survival. Cell Death Differ 15(9):1408-1416. https://doi. org/10.1038/cdd.2008.82

64. Truebestein L, Tennstaedt A, Monig T, Krojer T, Canellas F, Kaiser M, Clausen T, Ehrmann M (2011) Substrate-induced remodeling of the active site regulates human HTRA1 activity. Nat Struct Mol Biol 18(3):386-388. https://doi.org/10.1038/ nsmb. 2013

65. Caja F, Vannucci L (2015) TGFbeta: a player on multiple fronts in the tumor microenvironment. J Immunotoxicol 12(3):300-307. https://doi.org/10.3109/1547691X.2014.945667

66. Chu IM, Michalowski AM, Hoenerhoff M, Szauter KM, Luger D, Sato M, Flanders K, Oshima A, Csiszar K, Green JE (2012) GATA3 inhibits lysyl oxidase-mediated metastases of human basal triple-negative breast cancer cells. Oncogene 31(16):20172027. https://doi.org/10.1038/onc.2011.382

67. Park HJ, Gusarova G, Wang Z, Carr JR, Li J, Kim KH, Qiu J, Park YD, Williamson PR, Hay N, Tyner AL, Lau LF, Costa RH, Raychaudhuri P (2011) Deregulation of FoxM1b leads to tumour metastasis. EMBO Mol Med 3(1):21-34. https://doi.org/10.1002/ emmm.201000107

68. Sato S, Trackman PC, Maki JM, Myllyharju J, Kirsch KH, Sonenshein GE (2011) The Ras signaling inhibitor LOX-PP interacts with Hsp70 and c-Raf to reduce Erk activation and transformed phenotype of breast cancer cells. Mol Cell Biol 31(13):26832695. https://doi.org/10.1128/MCB.01148-10

69. Contente S, Kenyon K, Rimoldi D, Friedman RM (1990) Expression of gene rrg is associated with reversion of NIH 3T3 transformed by LTR-c-H-ras. Science 249(4970):796-798. https://doi. org/10.1126/science. 1697103

70. Kenyon K, Contente S, Trackman PC, Tang J, Kagan HM, Friedman RM (1991) Lysyl oxidase and rrg messenger RNA. Science 253(5021):802. https://doi.org/10.1126/science.1678898

71. Bais MV, Ozdener GB, Sonenshein GE, Trackman PC (2015) Effects of tumor-suppressor lysyl oxidase propeptide on prostate cancer xenograft growth and its direct interactions with DNA repair pathways. Oncogene 34(15):1928-1937. https://doi. org/10.1038/onc.2014.147

72. Payne SL, Hendrix MJ, Kirschmann DA (2007) Paradoxical roles for lysyl oxidases in cancer-a prospect. J Cell Biochem 101(6):1338-1354. https://doi.org/10.1002/jcb.21371

73. Levental KR, Yu H, Kass L, Lakins JN, Egeblad M, Erler JT, Fong SF, Csiszar K, Giaccia A, Weninger W, Yamauchi M, Gasser DL, Weaver VM (2009) Matrix crosslinking forces tumor progression 
by enhancing integrin signaling. Cell 139(5):891-906. https://doi. org/10.1016/j.cell.2009.10.027

74. Kasashima H, Yashiro M, Kinoshita H, Fukuoka T, Morisaki T, Masuda G, Sakurai K, Kubo N, Ohira M, Hirakawa K (2016) Lysyl oxidase is associated with the epithelial-mesenchymal transition of gastric cancer cells in hypoxia. Gastr Cancer 19(2):431442. https://doi.org/10.1007/s10120-015-0510-3

75. Cox TR, Rumney RMH, Schoof EM, Perryman L, Hoye AM, Agrawal A, Bird D, Latif NA, Forrest H, Evans HR, Huggins ID, Lang G, Linding R, Gartland A, Erler JT (2015) The hypoxic cancer secretome induces pre-metastatic bone lesions through lysyl oxidase. Nature 522(7554):106-110. https://doi.org/10.1038/natur e14492

76. Baker AM, Cox TR, Bird D, Lang G, Murray GI, Sun XF, Southall SM, Wilson JR, Erler JT (2011) The role of lysyl oxidase in SRC-dependent proliferation and metastasis of colorectal cancer. J Natl Cancer Inst 103(5):407-424. https://doi.org/10.1093/jnci/ djq569

77. Li RK, Zhao WY, Fang F, Zhuang C, Zhang XX, Yang XM, Jiang SH, Kong FZ, Tu L, Zhang WM, Yang SL, Cao H, Zhang ZG (2015) Lysyl oxidase-like 4 (LOXL4) promotes proliferation and metastasis of gastric cancer via FAK/Src pathway. J Cancer Res Clin Oncol 141(2):269-281. https://doi.org/10.1007/s0043 2-014-1823-Z

78. Samuel MS, Lopez JI, McGhee EJ, Croft DR, Strachan D, Timpson P, Munro J, Schroder E, Zhou J, Brunton VG, Barker N, Clevers H, Sansom OJ, Anderson KI, Weaver VM, Olson MF (2011) Actomyosin-mediated cellular tension drives increased tissue stiffness and beta-catenin activation to induce epidermal hyperplasia and tumor growth. Cancer Cell 19(6):776-791. https://doi. org/10.1016/j.ccr.2011.05.008

79. Chang J, Nicolau MM, Cox TR, Wetterskog D, Martens JW, Barker HE, Erler JT (2013) LOXL2 induces aberrant acinar morphogenesis via ErbB2 signaling. Breast Cancer Res 15(4):R67. https://doi.org/10.1186/bcr3461

80. Payne SL, Fogelgren B, Hess AR, Seftor EA, Wiley EL, Fong SF, Csiszar K, Hendrix MJ, Kirschmann DA (2005) Lysyl oxidase regulates breast cancer cell migration and adhesion through a hydrogen peroxide-mediated mechanism. Cancer Res 65(24):11429-11436. https://doi.org/10.1158/0008-5472. CAN-05-1274

81. Barker HE, Bird D, Lang G, Erler JT (2013) Tumor-secreted LOXL2 activates fibroblasts through FAK signaling. Mol Cancer Res 11(11):1425-1436. https://doi.org/10.1158/1541-7786. MCR-13-0033-T

82. Barry-Hamilton V, Spangler R, Marshall D, McCauley S, Rodriguez HM, Oyasu M, Mikels A, Vaysberg M, Ghermazien H, Wai C, Garcia CA, Velayo AC, Jorgensen B, Biermann D, Tsai D, Green J, Zaffryar-Eilot S, Holzer A, Ogg S, Thai D, Neufeld G, Van Vlasselaer P, Smith V (2010) Allosteric inhibition of lysyl oxidase-like-2 impedes the development of a pathologic microenvironment. Nat Med 16(9):1009-1017. https://doi.org/10.1038/ nm. 2208

83. Song G, Xu S, Zhang H, Wang Y, Xiao C, Jiang T, Wu L, Zhang $\mathrm{T}$, Sun X, Zhong L, Zhou C, Wang Z, Peng Z, Chen J, Wang $\mathrm{X}$ (2016) TIMP1 is a prognostic marker for the progression and metastasis of colon cancer through FAK-PI3K/AKT and MAPK pathway. J Exp Clin Cancer Res 35(1):148. https://doi. org/10.1186/s13046-016-0427-7

84. Omoto T, Kim-Kaneyama JR, Lei XF, Orimo A, Ohnishi K, Yoshihara K, Miyauchi A, Li S, Gao L, Umemoto T, Tanaka J, Nakahara K, Takeya M, Ishida F, Kudo SE, Haraguchi S, Miyazaki T, Miyazaki A (2018) The impact of stromal Hic-5 on the tumorigenesis of colorectal cancer through lysyl oxidase induction and stromal remodeling. Oncogene 37(9):1205-1219. https://doi.org/10.1038/s41388-017-0033-y
85. Thiery JP, Acloque H, Huang RY, Nieto MA (2009) Epithelial-mesenchymal transitions in development and disease. Cell 139(5):871-890. https://doi.org/10.1016/j.cell.2009.11.007

86. Peinado H, Iglesias-de Del Carmen, la Cruz M, Olmeda D, Csiszar K, Fong KS, Vega S, Nieto MA, Cano A, Portillo F (2005) A molecular role for lysyl oxidase-like 2 enzyme in snail regulation and tumor progression. EMBO J 24(19):3446-3458. https://doi. org/10.1038/sj.emboj.7600781

87. Canesin G, Cuevas EP, Santos V, Lopez-Menendez C, MorenoBueno G, Huang Y, Csiszar K, Portillo F, Peinado H, Lyden D, Cano A (2015) Lysyl oxidase-like 2 (LOXL2) and E47 EMT factor: novel partners in E-cadherin repression and early metastasis colonization. Oncogene 34(8):951-964. https://doi.org/10.1038/ onc. 2014.23

88. Zhang L, Huang G, Li X, Zhang Y, Jiang Y, Shen J, Liu J, Wang Q, Zhu J, Feng X, Dong J, Qian C (2013) Hypoxia induces epithelial-mesenchymal transition via activation of SNAI1 by hypoxiainducible factor - 1alpha in hepatocellular carcinoma. BMC Cancer 13:108. https://doi.org/10.1186/1471-2407-13-108

89. Zhang W, Shi X, Peng Y, Wu M, Zhang P, Xie R, Wu Y, Yan Q, Liu S, Wang J (2015) HIF-1alpha promotes epithelial-mesenchymal transition and metastasis through direct regulation of ZEB1 in colorectal cancer. PLoS One 10(6):e0129603. https://doi. org/10.1371/journal.pone.0129603

90. Erler JT, Bennewith KL, Cox TR, Lang G, Bird D, Koong A, Le QT, Giaccia AJ (2009) Hypoxia-induced lysyl oxidase is a critical mediator of bone marrow cell recruitment to form the premetastatic niche. Cancer Cell 15(1):35-44. https://doi.org/10.1016/j. ccr.2008.11.012

91. Kielosto M, Eriksson J, Nummela P, Yin M, Holtta E (2018) Divergent roles of lysyl oxidase family members in ornithine decarboxylase- and RAS-transformed mouse fibroblasts and human melanoma cells. Oncotarget 9(102):37733-37752. https ://doi.org/10.18632/oncotarget.26508

92. Li T, Wu C, Gao L, Qin F, Wei Q, Yuan J (2018) Lysyl oxidase family members in urological tumorigenesis and fibrosis. Oncotarget 9(28):20156-20164. https://doi.org/10.18632/oncotarget .24948

93. Kasashima H, Yashiro M, Okuno T, Miki Y, Kitayama K, Masuda G, Kinoshita H, Morisaki T, Fukuoka T, Hasegawa T, Sakurai K, Toyokawa T, Kubo N, Tanaka H, Muguruma K, Hirakawa K, Ohira M (2018) Significance of the lysyl oxidase members lysyl oxidase like 1, 3, and 4 in gastric cancer. Digestion 98(4):238248. https://doi.org/10.1159/000489558

94. Nilsson M, Adamo H, Bergh A, Halin Bergstrom S (2016) Inhibition of lysyl oxidase and lysyl oxidase-like enzymes has tumourpromoting and tumour-suppressing roles in experimental prostate cancer. Sci Rep 6:19608. https://doi.org/10.1038/srep19608

95. Misiorowski RL, Werner MJ (1978) Inhibition of lysyl oxidase by disulfhydryls, diamines and sulfhydryl-amines. Biochem Biophys Res Commun 85(2):809-814. https://doi.org/10.1016/0006$291 \times(78) 91234-2$

96. Tang SS, Chichester CO, Kagan HM (1989) Comparative sensitivities of purified preparations of lysyl oxidase and other amine oxidases to active site-directed enzyme inhibitors. Connect Tissue Res 19(1):93-103

97. Hajdu I, Kardos J, Major B, Fabo G, Lorincz Z, Cseh S, Dorman G (2018) Inhibition of the LOX enzyme family members with old and new ligands. Selectivity analysis revisited. Bioorg Med Chem Lett 28(18):3113-3118. https://doi.org/10.1016/j. bmcl.2018.07.001

98. Hornstra IK, Birge S, Starcher B, Bailey AJ, Mecham RP, Shapiro SD (2003) Lysyl oxidase is required for vascular and diaphragmatic development in mice. J Biol Chem 278(16):14387-14393. https://doi.org/10.1074/jbc.M210144200 
99. Martin A, Salvador F, Moreno-Bueno G, Floristan A, Ruiz-Herguido C, Cuevas EP, Morales S, Santos V, Csiszar K, Dubus P, Haigh JJ, Bigas A, Portillo F, Cano A (2015) Lysyl oxidase-like 2 represses Notch1 expression in the skin to promote squamous cell carcinoma progression. EMBO J 34(8):1090-1109. https:// doi.org/10.15252/embj.201489975
Publisher's Note Springer Nature remains neutral with regard to jurisdictional claims in published maps and institutional affiliations. 